\title{
Pendekatan dan Model Pelayanan BK Pola 17 Plus Jenis Layanan BK
}

\author{
Roma Ardika Sari (19035044) \\ Universitas Negeri Padang \\ Indonesia \\ E-mail : romaardika2@gmail.com
}

\begin{abstract}
Abstrak-Guidance and Counseling Service is a process of providing assistance to students continuously in order to achieve independence in self-understanding, so that students are able to direct themselves according to the demands and conditions of the school environment, family and community. Types of guidance and counseling services include: orientation services, information services, placement and distribution services, content mastery, individual services, group guidance services, group counseling services, consulting, mediation and advocacy.
\end{abstract}

Keywords-(Guaidance and counseling service, types of guidance and counseling)

\section{PENDAHULUAN}

Pelayanan bimbingan dan konseling di sekolah merupakan usaha membantu peserta didik dalam pengembangan kehidupan pribadi, kehidupan sosial, kegiatan belajar, serta perencanaan dan pengembangan karir. Pelayanan bimbingan dan konseling memfasilitasi pengembangan peserta didik secara individual, kelompok, dan atau klasikal, sesuai dengan kebutuhan, potensi, bakat, minat, perkembangan, kondisi, serta peluang- peluang yang dimiliki. Pelayanan ini juga membantu mengatasi kelemahan dan hambatan serta masalah yang dihadapi peserta didik. Dasar pemikiran penyelenggaraan bimbingan dan konseling di sekolah bukan semata-mata terletak pada ada atau tidak adanya landasan hukum (perundang-undangan) atau ketentuan dari atas, namun yang lebih penting adalah menyangkut upaya memfasilitasi peserta didik yang selanjutnya disebut konseli, agar mampu mengembangkan petensi dirinya atau mencapai tugas-tugas perkembangannya (menyangkut aspek fisik, emosi intelektual, sosial dan moralspiritual). Konseling sebagai seorang individu yang sedang berada dalam proses berkembang atau menjadi (onbecoming), yaitu berkembang ke arah kematangan atau kemandirian. Untuk mencapai kematangan tersebut, konseli memerlukan bimbingan karena mereka masih kurang memiliki pemahaman atau wawasan tentang dirinya dan lingkungannya, juga pengalaman yang menentukan arah kehidupannya. Di samping itu, terdapat suatu keniscayaan bahwa proses perkembangan konseli tidak selalu berlangsung secara mulus, atau bebas dari masalah. Dengan kata lain, proses perkembangan itu tidak selalu berjalan dalam alur linier, lurus, atau searah dengan potensi, harapan, dan nilai-nilai yang dianut. Sehingga layananlayanan seperti layanan orientasi, layanan informasi, layanan penempatan penyaluran, penguasaan konten dan konseling perseorangan di sekolah tidak dapat berjalan semestinya. Oleh karena itu perlu dilakukan pembahasan mengenai jenis- jenis layanan-layanan Bimbingan dan Konseling

\section{Metode PENELITIAN}

Dalam artikel ini penulis menggunakan metode penelitian yaitu library research atau study literature (Studi Kepustakaan). Dalam metode ini penulis memperoleh data dan informasi dari sumber bacaan berupa buku, jurnal, serta artikel yang akan dijadikan bahan rujukan untuk membuat artikel ilmiah ini. Tanpa harus terjun langsung kelapangan untuk memperoleh data dan informasi. Penulis akan mengutip materi dari beberapa sumber dan beberapa pendapat dari sebuah buku, jurnal maupun tulisan artikel yang lebih baik sebelumnya. Metode ini bertujuan agar pembaca dapat memahami apa isi pembahasan dengan beberapa rujukan yang sudah dicantumkan oleh penulis. Oleh karena itu, metode ini sangat tepat dalam pembuatan artikel sehingga diharapkan pembaca dapat memahami pembahasan dengan baik dalam artikel ini.

\section{KAJIAN TEORI DAN PEMBAHASAN}

\section{A. Pengertian Layanan $B K$}

Layanan Bimbingan dan Konseling merupakan proses pemberian bantuan yang diberikan kepada siswa secara terus menerus agar tercapai kemandirian dalam pemahaman diri, sehingga siswa sanggup mengarahkan dirinya sesuai dengan tuntutan dan keadaan lingkungan sekolah, keluarga dan masyarakat. Dengan adanya bimbingan dan konseling diharapkan dapat memberikan solusi bagi peserta didik disekolah. Agar peserta didik menjadi lebih baik dari segi perilakunya.

Layanan bimbingan dan konseling merupakan bagian integral dari pendidikan di Indonesia dalam upaya membantu siswa agar mencapai perkembangan yang optimal, sesuai dengan potensinya. Oleh karena itu, pelaksanaan bimbingan dan konseling disekolah menjadi tanggung jawab bersama antara personel sekolah, yaitu kepala sekolah, guru, konselor, dan pengawas ( Soeparaman. 2003).

\section{B. Jenis - jenis Layanan BK}

\section{Jenis Layanan Orientasi}

Layanan orientasi merupakan suatu layanan terhadap siswa disekolah yang berelasi dengan tatapan kedepan dan tentang sesuatu yang baru. Layanan orientasi ini biasanya 
diberikan saat siswa menginjakkan kaki ke sekolah barunya, pihak sekolah memberikan perkenalan tentang sekolah tersebut kepada siswa baru. Itu juga dilakukan oleh guru bidang studi memberikan perkenalan dan menjelaskan mekanisme pembelajaran dengannya sebelum masuk pada materi pembelajaran.

Sejalan dengan itu Prayitno (2009) menjelaskan bahwa layanan orientasi merupakan layanan bimbingan yang dilakukan untuk memperkenalkan peserta didik baru atau seseorang terhadap lingkungan baru yang dimasukinya. Sehingga Bagi peserta didik, ketidak kenalan atau ketidak tahuannya terhadap lingkungan lembaga pendidikan (sekolah) yang baru dimasukinya itu dapat memperlambat kelangsungan proses belajarnya kelak. Bahkan lebih jauh dari itu dapat membuatnya tidak mencapai hasil belajar yang diharapkan. Oleh sebab itu, diperlukannya layannan orientasi tentang lingkungan sekolah, Alasan diadakannya layanan orientasi peserta didik di sekolah adalah agar peserta didik siap menghadapi kondisi dan situasi sekolah yang baru. Bagaimanapun juga, kondisi dan situasi sekolah yang baru, akan berbeda dengan kondisi dan situasi sekolah yang lama.

Pada umumnya setiap sekilah pada awal tahun pelajaran pada pesrta didik baru akan melakukan pengenalan seperti pengenalan lingkungan fisik sekolah yang meliputi fasilitas sekolah dan lokasi kelas, laboratorium, dan UKS. Serta juga dilakukan pengenalan lingkungan sekolah meliputi kepala sekolah, guru-guru, tenaga pendidik, tetangga dilingkungan sekolah, teman sebaya, dan siswa ditingkat yang lebih tinggi.

Materi layanan Orientasi Bimbingan dan Konseling menurut Giyono (2015) meliputi :

1) Pelaksanaan kegiatan pembelajaran,

2) Lingkungan dan fasilitas sekolah yang menunjang kegiatan belajar,

3) Kurikulum sekolah, 4)Tugastugas,

5) Sistem ujian, penilaian, kenaikan kelas, dan UN,

6)Jenis dan system penetapan pilihan kegiatan ekstrakurikuler,

7) Pelayanan bimbingan dan konseling sebagai bagian dari kurikulum.

Menurut Fatmawati, H. R. (2013) Perencanaan Pelaksanaan Layanan Orientasi merupakan rencana kegiatan yang akan dilakukan atau dilaksanakan. Program perencanaan pelaksanaan layanan orientasi dan informasi termuat dalam program tahunan, maupun program semester dan program mingguan bimbingan konseling. Ada pun penyusunan programnya dilakukan melalui tiga tahap, yaitu:

a. Melakukan Pengkajian Terhadap Kegiatan

Salah satu kegiatan layanan orientasi dan informasi adalah pengenalan keberadaan masing-masing bidang, kurikulum, sarana yang ada di sekolah atau informasi penjurusan. Kajian program dilaku kan dengan melakukan analisis terhadap lingkungan sekolah baik untuk mengetahui kondisi yang lalu, saat ini maupun yang akan datang. Dari analisis tersebut kegiatan mana yang harus dilaksana- kan, ditambah atau dikurangi.

b. Merumuskan Program Kegiatan Layanan Orientasi dan Informasi
Setelah dilakukan analisis terhadap rencana kegiatan yang akan dilaksanakan, maka selanjutnya merumuskan sebuah program. Program yang telah disusun akan dijadikan sebagai pedoman pelaksanaan kegiatan. Dalam merumuskan program kegiatan yang dijadikan bahan pertimbangan antara lain: tujuan, subyek sasaran, jenis kegiatan, narasumber dan target kegiatan, apakah sudah sesuai dengan kebutuhan serta minat peserta didik. Dengan demikian perencanaan tadi akan mencapai target yang diiginkan dan mencapai sasaran mutu kegiatan.

c. Sosialisasi Program

Agar kegiatan layanan orientasi dan informasi yang akan dilaksanakan mendapatkan dukungan dari semua pihak, maka perlu dilakukan sosialisasi program baik terhadap guru melalui rapat dinas, atau terhadap orang tua peserta didik melalui pertemuan pada saat pengambilan laporan hasil belajar atau pun dengan mengunakkan berbagai media.

\section{Jenis Layanan Informasi}

Layanan informasi adalah layanan yang dilakukan untuk memberikan informasi atau pemahaman kepada individuindividu yang berkepentingan tentang berbagai hal yang diperlukan untuk menjalani suatu tugas atau kegiatan sesuai dengan tujuan. Dengan adanya layanan ini akan membantu peserta didik menjadi terbimbing dan mempunyai pedoman informasi mengenai masa depan peserta didik tersebut.

Sejalan dengan itu Nursalim (2002) menjelaskan bahwa layanan informasi dimaksudkan untuk membantu siswa mengenal lingkungan yang informasi tersebut dapat dimanfaatkan untuk masa kini maupun masa yang akan datang. Tujuan dari layanan informasi yaitu untuk membekali individu dengan berbagai pengetahuan dan pemahaman tentang berbagai hal yang berguna untuk mengenal diri, merencanakan dan mengembangkan pola kehidupan sebagai pelajar, anggota keluarga, dan masyarakat.

Tri Hariastuti (2008) berpendapat bahwa pemahaman yang diperoleh melalui layanan informasi digunakan sebagai bahan acuan dalam meningkatkan kegiatan dan prestasi belajar, mengembangkan cita- cita, menyelenggarakan kehidupan sehari-hari dan mengambil keputusan. Jadi tujuan layanan informasi secara umum agar terkuasainya informasi tertentu sedangkan secara khusus terkait dengan fungsi pemahaman (paham terhadap informasi yang diberikan) dan memanfaatkan informasi dalam penyelesaian masalahnya.

Layanan informasi menjadikan individu mandiri yaitu memahami dan menerima diri dan lingkungan secara positif, objektif dan dinamis, mampu mengambil keputusan, mampu mengarahkan diri sesuai dengan kebutuhannya tersebut dan akhirnya dapat mengaktualisasikan dirinya dan layanan informasi diadakan untuk membekali para siswa dengan pengetahuan tentang data dan fakta di bidang pendidikan sekolah, bidang pekerjaan dan bidang perkembangan pribadisosial, supaya mereka dengan belajar tentang lingkungan hidupnya lebih mampu mengatur dan merencanakan kehidupannya sendiri. 
Ada tiga alasan utama mengapa pemberian informasi perlu diselenggarakan yaitu:

a. Membekali individu dengan berbagai pengetahuan tentang lingkungan yang diperlukan untuk memecahkan masalah yang dihadapi berkenaan dengan lingkungan sekitar, pendidikan, jabatan, maupun sosial budaya.

b. Memungkinkan individu dapat menentukan arah hidupnya

c. Setiap individu adalah unik

Adapun tujuan dari layanan informasi adalah untuk membekali individu dengan berbagai pengetahuan dan pemahaman tentang berbagai hal yang berguna untuk mengenal diri, merencanakan, dan mengembangkan pola kehidupan sebagai pelajar, anggota keluarga dan masyarakat. Pemahaman yang diperoleh melalui layanan informasi, digunakan sebagai bahan acuan dalam meningkatkan kegiatan dan prestasi belajar, mengembangkan cita-cita, menyelenggarakan kehidupan sehari-hari, dan dalam mengambil keputusan.

Materi yang dapat diangkat melalui layanan informasi khususnya dalam rangka pelayanan bimbingan dan konseling yaitu: informasi pendidikan, informasi jabatan, dan informasi sosial budaya. Dari ketiga jenis informasi tersebut dapat digabungkan sebagai berikut:

a. Tugas-tugas perkembangan masa remaja tentang kemampuan dan perkembangan pribadi.

b. Usaha yang dapat dilakukan dalam mengenal bakat, minat, serta bentuk-bentuk penyaluran dan pengembangannya.

c. Tata tertib sekolah, cara bertingkah laku, tata karma, dan sopan santun.

d. Nilai-nilai sosial, adat istiadat, dan upaya yang berlaku dan berkembang di masyarakat.

e. Mata pelajaran dan pembidangannya seperti program inti, program khusus, dan program tambahan.

f. System penjurusan, kenaikan kelas, syarat-syarat mengikuti ujian akhir.

g. Fasilitas penunjang dan sumber belajar.

h. Cara mempersiapkan diri dan belajar di sekolaah.

i. Syarat-syarat memasuki suatu jabatan, kondisi jabatan atau karier serta prospeknya.

j. Langkah-langkah yang ditempuh guna mendapatkan jabatan.

k. Memasuki perguruan tinggi yang sejalan dengan citacita karier.

1. Pelaksanaan layanan bantuan unuk masalah pribadi, sosial, belajar, dan karier

\section{Jenis Layanan Penempatan Penyaluran}

Layanan penempatan penyaluran yaitu layanan yang memungkinkan peserta didik memperoleh penempatan dan penyaluran yang tepat yang sesuai dengan potensi, bakat, dan minat serta kondisi pribadi, sehingga perencanaan karier dapat dilaksanakan dengan baik melalui layanan-layanan yang ada pada bimbingan konseling. Pelaksanaan layanan penempatan/penyaluran di sekolah harus mendapat dukungan dari semua pihak sekolah agar terlaksana dengan baik, karena dukungan layanan ini termasuk yang penting untuk perencanaan karier siswa. Tujuan agar setiap individu dapat mengembangkan diri secara optimal tentunya dengan kemampuan yang ada dalam diri invidu.

Penempatan dan penyaluran siswa disekolah dapat berupa:

1). Penempatan siswa didalam kelas.

2). Penempatan dan penyaluran ke dalam kelompok belajar.

3).Penempatan kedalam ekstrakulikuler.

4).Penempatan kedala jurusan/program.

Menurut ABKIN (2013:40), proses pelaksanaan layanan penempatan dan penyaluran dapat dilaksanakan dengan berbagai cara yang berbeda, khususnya pada layanan peminatan dapat dilaksanakan dengan salah satu dari dua alternatif, diantaranya: Alternatif pertama, yaitu proses pemilihan dan penetapan peminatan peserta didik bersamaan dengan penerimaan peserta didik baru (PPDB). Untuk kelancaran proses dan ketepatan hasil kerja, maka ada beberapa kegiatan yang perlu dilaksanakan oleh sekolah, secara keseluruhan yaitu:

a. Menetapkan kuota peserta didik dan bidang peminatan yang akan diselenggarakan.

b. Menetapkan syarat pendaftaran sebagai calon peserta didik baru.

c. Menetapkan komponen dan kriteria peminatan belajar bagi peserta didik baru.

d. Mengumumkan kuota, bidang peminatan belajar, syarat pendaftaran calon peserta didik baru, syarat pendaftaran ulang peserta didik baru, tata tertib sekolah dan waktu mulainya pembelajaran tahun pelajaran baru kepada calon peserta didik baru atau masyarakat luas melalui papan pengumuman di sekolah, media cetak setempat, dan website sekolah.

e. Memfasilitasi dan menugaskan Guru BK

Kemudian alternatif kedua, yaitu proses pemilihan dan penetapan peminatan peserta didik dilaksanakan pada minggu pertama awal tahun pelajaran baru setelah calon peserta didik baru dinyatakan diterima sebagai peserta didik baru.

Langkah yang dilakukan meliputi:

a. Memberikan informasi dan orientasi tentang macam dan kuota peminatan, mekanisme, komponen dan kriteria yang digunakan dalam pemilihan/ penetapan, kriteria penetapan

b. Menyiapkan dan menggunakan instrumen dan atau format peminatan untuk mengumpulkan data peminatan peserta didik dan orangtuanya

c. Mengumpulkan data peminatan peserta didik baik data dokumentasi, observasi, maupun wawancara, serta analisis data peminatan yang terkumpul

d. Menetapkan peminatan peserta didik berdasarkan hasil analisis.

e. Melayani konsultasi peminatan bagi peserta didik dan atau orangtua.

f. Mengelompokkan rombongan belajar berdasarkan peminatan peserta didik dan satuan kelas. 


\section{Jenis Layanan Penguasaan Konten}

Bimbingan dan Konseling dalam memberikan layanan kepada siswa, salah satunya adalah memberikan pemahaman kesadaranakan keragaman budaya untuk meningkatkan hubungan interpersonal siswa melalui layanan penguasaan konten. Layanan penguasaan konten adalah salah satu layanan bimbingan dan konseling yang bertujuan untuk membantu siswa memiliki kompetensi atau konten tertentu agar bermanfaat untuk perkembangannya, baik diri sendiri maupun lingkungan. Layanan penguasaan konten dengan kegiatan parenting day, bulan gizi dan lainnya. Kesembilan : Layanan pendukung seperti layanan konsultasi, Mediasi, Aplikasi, kolaborasi dengan guru MAPEL atau wali kelas, Koordinasi dengan orang tua.

Dalam proses pembelajaran yang efektif di sekolah, tidak semua siswa mampu mengoptimalkan kemampuan belajarnya dengan baik, maka diperlukan guru pembimbing untuk memberikan informasi tentang layanan penguasaan konten atau pembelajaran untuk memberi bantuan kepada siswa berkenaan dengan permasalahan akademik (Arikunto 2011).

Permasalahan akademik dapat diberikan dengan layanan penguasaan konten bahwa kegagalan-kegagalan yang dialami siswa dalam belajar tidak selalu disebabkan oleh kebodohan atau rendahnya intelegensi. Kegiatan dalam layanan penguasaan konten dapat berhasil dan mencapai tujuan yang akan dicapai, maka yang digunakan dalam langkah-langkah ini harus disusun dan dijalankan secara baik. Dalam hal ini pelaksanaan layanan penguasaan konten yang digunakan perencanaan, pelaksanaan, evaluasi atau penilaian, dan tindak lanjut (Tohirin 2011).

Sehingga diperlukan materi seperti: Pengenalan siswa yang mengalami masalah belajar, Pengembangan motivasi, sikap dan kebiasaan belajar yang baik, pengajaran perbaikan, dan pengayaan (Prayitno dan Amti, 2008).

Media yang digunakan oleh guru bimbingan dan konseling dalam layanan penguasaan konten yaitu: media visual adalah visualisasi pesan, informasi, atau konsep yang ingin disampaikan kepada siswa dapat dikembangakan dalam berbagai bentuk, seperti foto, gambar/ilustrasi, sketsa/gambar garis, grafik, bagan, chart, dan gambungan dari dua bentuk atau lebih (Arsyad, 2010), sedangkan media audiovisual adalah media yang melibatkan pendengaran dan pengelihatan sekaligus dalam satu proses.

\section{Jenis Layanan Konseling Perorangan}

Menurut Prayitno (2004:1), konseling perorangan merupakan layanan konseling yang diselenggarakan oleh konselor terhadap seorang klien dalam rangka pengentasan masalah pribadi klien. Masalah dominan yang dialami oleh siswa menurut guru bimbingan dan konseling yaitutentang keterlambatan, kedisiplinan, susah berkonsentrasi dan membolos. Cara penanganan yang dilakukan untuk mengatasi masalah yang dihadapi siswa.

Peran guru bimbingan dan konseling dalam menyelesaikan masalah yang dialami sesuai dengan kebutuhan siswa. Hal ini dilakukan untuk dapat lebih mengoptimalkan rencana penanganan yang akan dilakukan. Apabila siswa yang bermasalah berjumlah satu maka akan diberilayanan konseling individu. Namun apabila jumlahnya lebih dari satumaka akan diberi layanan konseling kelompok. Tindak lanjut yang dilakukan oleh gru Bimbingan dan konseling adalah dengan melakukan pemantauan kepada siswa yang bersangkutan. Apabila siswa yang bersangkutan belum berubah setelah diberi layanan maka siswa tersebut akan dikonseling lagi. Tujuan umum merupakan tujuan keseluruhan yang ingin dicapai melalui kegiatan konseling perorangan.

Menurut Prayitno (2004:4) tujuan umum dari pelaksanaan konseling perorangan adalah apabila masalah klien itu dicirikan sebagai sesuatu yang tidak disukai adanya, sesuatu yang ingin dihilangkan dan atau sesuatu yang dapat menghambat atau menimbulkan kerugian, maka upaya pengentasan masalah klien melalui konseling perorangan akan mengurangi intentsitas ketidaksukaan atas keberadaan sesuatu yang dimaksud, atau meniadakan keberadaan sesuatu yang dimaksud dan atau mengurangi intensitas hambatan dan atau kerugian yang ditimbulkan oleh suatu yang dimaksudkan itu. Melalui layanan konseling perorangan, diharapkan terentaskan masalah yang dialami oleh, maka fungsi pengentasan sangat dominan dalam layanan ini.

\section{KESIMPULAN}

Layanan Bimbingan dan Konseling merupakan proses pemberian bantuan yang diberikan kepada siswa secara terus menerus agar tercapai kemandirian dalam pemahaman diri, sehingga siswa sanggup mengarahkan dirinya sesuai dengan tuntutan dan keadaan lingkungan sekolah, keluarga dan masyarakat. Jenis-jenis layanan bimbingan dan konseling meliputi: layanan orientasi, layanan informasi, layanan penempatan dan penyaluran, layanan penguasaan konten, layanan perseorangan. Keterkaitan antara layanan dengan tujuan visi dan misi bimbingan dan konseling yaitu untuk mengenal diri sendiri dan lingkungannya, untuk dapat menerima diri sendiri lingkungannya secara positif dan dinamis, untuk dapat mengarahkan diri sendiri, untuk dapat mewujudkan diri sendiri, untuk dapat mengambil keputusan sendiri tentang berbagai hal.

\section{Daftar Pustaka}

Arikunto, Suharsimi. (2011). Penilian dan Penelitian Bidang Bimbingan dan Konseling . Yogyakarta: Aditya Media.

Fatmawati, H. R. (2013). Pelaksanaan Praktik Bimbingan Konseling Layanan Orientasi dan Informasi Berdasarkan Manajemen Mutu. ISO 9001: 2008. Jurnal Kebijakan dan Pengembangan Pendidikan, 1(2).

Giyono.(2015).Bimbingan Konseling. Yogyakarta: Media Akademi.

Karina, Windi.(2017). Layanan BK disekolah Islam dan Khatolik (Studi Komparatif pada SMP Muhammadiyah 2 Yogyakarta dan SMP Stella Duce 1 Yogyakarta). 
HISBAH: Jurnal Bimbingan Konseling dan Dakwah Islam Vol. 14, No. 2.

Nursalim, Mochamad \& Suradi. (2002). Layanan Bimbingan dan Konseling. Surabaya: Unesa University Press.

Prayitno dan Amti, E. (2004). Dasar-Dasar Bimbingan dan Konseling. Jakarta: RinekaCipta.

Prayitno dan Amti, Erman. (2008). Dasar-Dasar Bimbingan Konseling. Jakarta: Rineka Cipta.

Prayitno dan Erman A. (2009). Dasar-dasar Bimbingan dan Konseling. Jakarta: Pusat Perbukuan Depdiknas.
Puspita, D., \& Amalia, R. (2020). Koordinasi Bimbingan Konseling Dengan Guru Bidang Studi Menghadapi Siswa Berkesulitan Belajar Mateatika. Jurnal Pendidikan dan Konseling (JPDK), 1(2), 1-7.

TIM. (2013). Modul Pelatihan Implementasi Kurikulum2013 untuk Guru BK/ Konselor : Implementasi Pelayanan Bimbingan dan Konseling . Jakarta: Kemendikbud.

Tohirin. (2011). Bimbingan dan Konseling Di sekolah dan Madrasah (Berbasis integrasi). Jakarta: Rajawali Prees.

Tri Hariastuti, Retno. 2008. Dasar-dasar Bimbingan dan Konseling. Surabaya: Unesa University Press. 